\title{
KAJIAN MODULUS ELASTISITAS PADA BETON MUTU TINGGI MEMADAT MANDIRI DENGAN VARIASI PENAMBAHAN BAHAN METAKAOLIN
}

\author{
Wibowo'), Antonius Mediyanto'), dan Putri Lathifah ${ }^{3)}$ \\ 1) Pengajar Fakultas Teknik, Prodi Teknik Sipil, Universitas Sebelas Maret \\ 2) Pengajar Fakultas Teknik, Prodi Teknik Sipil, Universitas Sebelas Maret \\ 3) Mahasiswa Fakultas Teknik, Prodi Teknik Sipil, Universitas Sebelas Maret \\ J1. Ir. Sutami 36A, Surakarta 57126; Telp.0271-634524. Email: lalaputri97@gmail.com
}

\begin{abstract}
High strength concrete with Metakaolin (MK) material addition is an innovation of the advancement in construction world having a very fast development. Metakalin is used to substitute some of the cement total weight in which in this research the metakaolin amount used is $M K 0 \%$; MK $12.5 \% ; M K 17.5 \% ; M K 22.5 \%$; and MK 27.5\%. This research aimed to determine the effect of metakaolin as partial cement substitution material toward the elasticity modulus of high strength self-compacting concrete (HSSCC) in the concrete age of 28 days using cylindrical speciment with $75 \mathrm{~mm}$ diameter and $150 \mathrm{~mm}$ height. This research used experimental method. The concrete made by adding metakaolin didn't meet the requirements for self-compacting concrete (SCC), but it did for high strength concrete. The highest elasticity modulus was produced in the 12.5\% amount of metakaolin from the cement weight. Then, the calculation which take ASTM C469 and Eurocode 2-1992 as a standard, showed that the optimum amount of metakaolin was $12.18 \%$ and $12.42 \%$ with the optimum elasticity modulus of $37594.73 \mathrm{MPa}$ and $37368.04 \mathrm{MPa}$.
\end{abstract}

Key words: Metakaolin, HSSCC, elasticity modulus.

\begin{abstract}
Abstrak
Beton mutu tinggi dengan penambahan bahan Metakaolin (MK) merupakan inovasi untuk kemajuan dunia konstruksi yang memiliki perkembangan sangat pesat. Metakaolin digunakan untuk mengganti sebagian dari total berat semen yang dalam penelitian ini kadar metakaolin yang digunakan adalah MK 0\%; MK 12,5\%; MK 17,5\%; MK 22,5\% ; dan MK 27,5\%. Penelitian ini bertujuan mengetahui pengaruh variasi penambahan metakaolin dari berat semen terhadap modulus elastisitas beton high strength self-compacting concrete (HSSCC) pada usia beton 28 hari dengan benda uji silinder berukuran diameter $75 \mathrm{~mm}$ dan tinggi $150 \mathrm{~mm}$. Metode yang digunakan dalam penelitian ini adalah eksperimental. Hasil dari variasi penambahan bahan metakaolin dalam penelitian ini tidak memenuhi syarat self-compacting concrete (SCC), akan tetapi memenuhi syarat sebagai beton mutu tinggi atau high strength. Modulus elastisitas maksimum dihasilkan pada kadar 12,5\% metakaolin. Kemudian, diperoleh kadar optimum hasil penghitungan berdasarkan ASTM C469 dan Eurocode 2-1992 yaitu 12,18\% dan 12,42\% dengan modulus elastisitas yang dihasilkan sebesar 37594,73 MPa dan 37368,04 MPa.
\end{abstract}

Kata kunci: Metakaolin, HSSCC, modulus elastisitas.

\section{PENDAHULUAN}

Perkembangan paling revolusioner dalam dunia konstruksi adalah beton memadat mandiri atau self-compacting concrete (SCC), beton yang mampu mengalir dengan beratnya sendiri mengisi keseluruhan bekisting bahkan dapat melewati tulangan padat yang memiliki jarak tertentu dan memadat tanpa diperlukan alat penggetar atau vibrator dengan mempertahankan homogenitas campuran. Penciptaan mutu beton yang lebih baik terus dilakukan, beton mutu tinggi memadat mandiri atau high strength self-compacting concrete (HSSCC) adalah beton SCC yang memiliki mutu tinggi dengan adanya penambahan superplasticizer (SP) sebagai polimer yang mampu menghasilkan workability yang diperlukan pada beton.

Metakaolin adalah bahan dasar alternatif sebagai hasil dari pemanasan kaolin pada suhu $500{ }^{\circ} \mathrm{C}-900{ }^{\circ} \mathrm{C}$ yang digunakan untuk bahan pengganti semen. Penambahan metakaolin dalam campuran beton dapat meningkatkan kerapatan yang menghasilkan kualitas beton lebih bagus. Metakaolin memiliki ukuran partikel lebih kecil dari silica fume sehingga sebagai pozzolan metakaolin dapat mempercepat proses hidrasi dan mengurangi waktu setting beton. Penambahan metakaolin dalam penelitian ini diharapkan dapat meningkatkan modulus elastisitas beton dengan disyaratkan kuat tekan beton yang dihasilkan tinggi, serta mengurangi porositas dan permeabilitas beton.

Modulus elastisitas dan kuat tekan beton merupakan parameter utama mutu beton. Semakin kuat struktur yang diinginkan maka semakin besar modulus elastisitas pada beton. Modulus elastisitas diperoleh dari pengujian benda uji atau sample beton berbentuk silinder dengan ukuran diameter $75 \mathrm{~mm}$ dan tinggi silinder $150 \mathrm{~mm}$. Semakin tinggi nilai kuat tekan beton akan berbanding lurus dengan nilai modulus elastisitas beton yang juga semakin tinggi. Modulus elastisitas berkaitan erat dengan kekuatan bahan pada beton yang akan menerima beban, reaksi yang terjadi mengakibatkan perubahan tegangan dan regangan pada beton. Modulus elastisitas tinggi menunjukkan rasio tegangan terhadap regangan yang dihasilkan tinggi sehingga lendutan yang terjadi pada beton kecil. 


\section{LANDASAN TEORI}

Beton berkualitas baik adalah beton yang tidak keropos/porous, kedap air dan menghasilkan kuat tekan tinggi. Keawetan beton menjadi rendah apabila tingkat permeabilitas dan porousitas yang tinggi sehingga beton tidak dapat digunakan sesuai dengan masa layannya. Oleh sebab itu diperlukan metode baru dan teknologi untuk pengecoran beton agar merata dan terjaga homogenitas campuran beton. Salah satu solusinya adalah dengan penggunaan beton memadat mandiri (self compacting concrete- SCC) (As'ad, 2012).

Beton merupakan bahan yang bersifat getas, nilai kuat tekan beton relatif lebih tinggi dibandingkan dengan kuat tarik beton. Kuat tarik yang dimiliki beton hanya berkisar antara 9\% - 15\% dari kuat tekan beton, karena itu sering kali dalam perencanaan kuat tarik beton dianggap sama dengan nol (Dipohusodo,1994). Beton mutu tinggi (bigh strength concrete) yang tercantum dalam SNI 03-6468-2000 didefinisikan sebagai beton yang mempunyai kuat tekan yang disyaratkan lebih besar sama dengan 41,4 MPa.

Penambahan variasi metakaolin pada campuran beton mutu tinggi memadat mandiri dapat meningkatkan kuat tekan beton, tetapi workabilitas pada beton menurun seiring dengan meningkatnya penambahan metakaolin pada campuran beton (Emir, 2017). Penggunaan proporsi faktor air semen yang semakin meningkat mengakibatkan kuat tekan beton semakin berkurang pada penambahan kadar metakaolin yang sama (Kasim, 2007). Disisi lain, penambahan metakaolin mempercepat proses hidrasi semen. Pada reaksi, CSH terhidrasi dan aluminium menggantikan silikon di rantai CSH sehingga didapatkan beton berkekuatan tinggi, menghasilkan porositas yang rendah pada beton, dan memiliki diameter pori kecil (Shen, 2017).

\section{METODE}

Metode yang digunakan dalam penelitian ini adalah metode percobaan (eksperimental) dengan parameter yang dikaji yaitu workability, tegangan-regangan, dan modulus elastisitas beton. Penelitian dilakukan dengan pengujian sample berbentuk silinder yang berukuran diameter $75 \mathrm{~mm}$ dan tinggi $150 \mathrm{~mm}$ dengan umur beton 28 hari. Benda uji yaitu beton HSSCC dengan variasi penambahan kadar metakaolin yang berbeda-beda yaitu $0 \% ; 12,5 \% ; 17,5 \%$ ; 22,5\% dan 27,5\%. Benda uji dibuat tiga buah sample per variasi kadar metakaolin dijabarkan pada Tabel 1.

Tabel 1. Jumlah kebutuhan benda uji

\begin{tabular}{cccccc}
\hline No. & $\begin{array}{c}\text { Kadar } \\
\text { Metakaolin }\end{array}$ & Kode Benda Uji & $\begin{array}{c}\text { Umur Beton } \\
\text { (hari) }\end{array}$ & Parameter Beton & $\begin{array}{c}\text { Jumlah } \\
\text { Benda Uji }\end{array}$ \\
\hline 1. & $0 \%$ & HSSCC MK 0 & 28 & Modulus Elastisitas & 3 \\
\hline 2. & $12,5 \%$ & HSSCC MK 12,5 & 28 & Modulus Elastisitas & 3 \\
\hline 3. & $17,5 \%$ & HSSCC MK 17,5 & 28 & Modulus Elastisitas & 3 \\
\hline 4. & $22,5 \%$ & HSSCC MK 22,5 & 28 & Modulus Elastisitas & 3 \\
\hline 5. & $27,5 \%$ & HSSCC MK 27,5 & 28 & Modulus Elastisitas & 3 \\
\hline \multicolumn{5}{r}{ Total Benda Uji (Sample) } & \\
\hline
\end{tabular}

\section{Mix Design atau Rancang Campur Adukan Beton}

Rancang campur beton mutu tinggi memadat mandiri atau HSSCC dengan variasi penambahan bahan metakaolin penelitian ini berdasarkan EFNARC 2005. Mengacu pada penelitian sebelumnya, kadar superplasticizer Viscocrete 1003 yang digunakan 1,7\% dari berat semen (kadar optimum pada penelitian sebelumnya) dengan faktor air semen yang digunakan 0,27. Rekapitulasi mix design atau rancang campur adukan beton diuraikan pada Tabel 2. 
Tabel 2. Rekapitulasi mix design atau rancang campur adukan beton

\begin{tabular}{lcccccc}
\hline \multirow{2}{*}{$\begin{array}{l}\text { Nama } \\
\text { Benda Uji }\end{array}$} & \multicolumn{2}{c}{ Agregat } & \multicolumn{2}{c}{ Sementitius } & Agregat \\
\cline { 2 - 5 } & $\begin{array}{c}\text { Halus } \\
\left(\mathrm{Kg} / \mathrm{m}^{3}\right)\end{array}$ & $\begin{array}{c}\text { Agregat } \\
\text { Kasar } \\
\left(\mathrm{Kg} / \mathrm{m}^{3}\right)\end{array}$ & $\begin{array}{c}\text { Semen } \\
\left(\mathrm{Kg} / \mathrm{m}^{3}\right)\end{array}$ & $\begin{array}{c}\text { Metakaolin } \\
\left(\mathrm{Kg} / \mathrm{m}^{3}\right)\end{array}$ & $\begin{array}{c}\text { Superplasticizer } \\
\left(\mathrm{lt} / \mathrm{m}^{3}\right)\end{array}$ & $\begin{array}{c}\text { Air } \\
\left(\mathrm{lt} / \mathrm{m}^{3}\right)\end{array}$ \\
\hline $\begin{array}{l}\text { HSSCC } \\
\text { MK 0 }\end{array}$ & 921,13 & 765,98 & 600,00 & 0,00 & 10,20 & 162,00 \\
\hline $\begin{array}{l}\text { HSSCC } \\
\text { MK 12,5 }\end{array}$ & 914,64 & 760,59 & 525,00 & 75,00 & 10,20 & 162,00 \\
\hline $\begin{array}{l}\text { HSSCC } \\
\text { MK 17,5 }\end{array}$ & 912,04 & 758,43 & 495,00 & 105,00 & 10,20 & 162,00 \\
\hline $\begin{array}{l}\text { HSSCC } \\
\text { MK 22,5 }\end{array}$ & 909,44 & 756,27 & 465,00 & 135,00 & 10,20 & 162,00 \\
\hline $\begin{array}{l}\text { HSSCC } \\
\text { MK 27,5 }\end{array}$ & 906,85 & 754,11 & 435,00 & 165,00 & 10,20 & 162,00 \\
\hline
\end{tabular}

\section{Persamaan yang Digunakan}

Kuat tekan beton $\left(f^{\prime} c\right)$

Pengujian kuat tekan beton dilakukan saat umur beton 28 hari dengan menggunakan alat universal testing machine (UTM) di Laboratorium material program studi teknik mesin Universitas Sebelas Maret, Surakarta. Hasil dari pembacaan mesin UTM adalah beban maksimum (Pmaks). Data beban maskimum tersebut dapat diolah dan menghasilkan nilai kuat tekan beton dengan menggunakan Persamaan 1.

$f^{\prime} \mathrm{c}=\frac{\mathrm{P}}{\mathrm{A}}$

dengan $f^{\prime} c=$ kuat tekan beton $\left(\mathrm{N} / \mathrm{mm}^{2}\right), \mathrm{P}=$ beban desak maksimum $(\mathrm{N}), \mathrm{A}=$ luas permukaan benda uji $\left(\mathrm{mm}^{2}\right)$.

Modulus elastisitas beton (Ec)

Penghitungan modulus elastisitas menggunakan beberapa rumus empiris yang sudah diketahui. Hasil hitungan dibedakan menjadi 2 (dua) yaitu berdasarkan hasil eksperimen dan berdasarkan hasil prediksi. Berdasarkan hasil eksperimen dapat dihitung dengan Persamaan 2 dan Persamaan 3.

Persamaan berdasarkan ASTM C469

$\mathrm{Ec}=\frac{0,4 f^{\prime} \mathrm{c}-\sigma_{1}}{\varepsilon\left(0,4 f^{\prime} \mathrm{c}\right)-\varepsilon_{1}}$

dengan $\mathrm{Ec}=$ modulus elastisitas $(\mathrm{MPa}), \mathcal{E}_{1}=$ regangan aksial $50 \times 10^{-6}(\mathrm{~mm} / \mathrm{mm}), \sigma_{1}=$ tegangan yang berhubungan dengan $\mathcal{E}_{1}(\mathrm{MPa}), f^{\prime} c=$ kuat tekan beton uji silinder 28 hari $(\mathrm{MPa})$.

Persamaan Eurocode 2-1992

$\mathrm{Ec}=\frac{0,4 f^{\prime} \mathrm{c}}{\mathcal{E}\left(0,4 f^{\prime} \mathrm{c}\right)}$, interval $\sigma=0-\sigma=0,4 f^{\prime} \mathrm{c}$

dengan Ec $=$ modulus elastisitas statik $(\mathrm{MPa}), \mathcal{E}=$ regangan aksial $(\mathrm{mm} / \mathrm{mm}), f^{\prime} c=$ kuat tekan beton uji silinder 28 hari $(\mathrm{MPa})$.

Penghitungan modulus elastisitas berdasarkan hasil prediksi dapat dihitung dengan Persamaan 4 sampai dengan Persamaan 9.

Persamaan berdasarkan ACI Committee 363-10

$\mathrm{Ec}=3320 \sqrt{f^{\prime} \mathrm{c}}+6900,\left[\right.$ High-strength concrete, $\left.f^{\prime} c \leq 83 \mathrm{MPa}\right]$ 
dengan $f^{\prime} c=$ kuat tekan beton uji silinder 28 hari $(\mathrm{MPa})$.

Persamaan berdasarkan Eurocode 2-1992

$\mathrm{Ec}=9500\left(f^{\prime} \mathrm{c}+8\right)^{0,33}$

dengan $f^{\prime} c=$ kuat tekan beton uji silinder 28 hari (MPa).

Persamaan berdasarkan Kollmorgen

$\mathrm{Ec}=11800\left(f^{\prime} \mathrm{c}\right)^{1 / 3,14},\left[34 \leq f^{\prime} c \leq 207 \mathrm{MPa}\right]$

dengan $f^{\prime} c=$ kuat tekan beton uji silinder 28 hari (MPa).

Persamaan berdasarkan Norwegian Standard NS 3473

$\mathrm{Ec}=9500\left(f^{\prime} c\right)^{0,3},\left[25 \leq f^{\prime} c \leq 85 \mathrm{MPa}\right]$

dengan $f^{\prime} c=$ kuat tekan beton uji silinder 28 hari (MPa).

Persamaan berdasarkan Norwegian Code

$\mathrm{Ec}=9500\left(f^{\prime} \mathrm{c}\right)^{0,3}(w / 2400)^{1,5}$

dengan $f^{\prime} c=$ kuat tekan beton uji silinder 28 hari $(\mathrm{MPa}), w=$ berat volume beton $\left(\mathrm{kg} / \mathrm{m}^{3}\right)$.

Persamaan berdasarkan SNI 2847-2013

$\mathrm{Ec}=0,043\left(w_{c}\right)^{1,5}\left(f^{\prime} \mathrm{c}\right)^{0,5},\left[1500 \leq w_{\mathrm{c}} \leq 2500 \mathrm{kgf} / \mathrm{m}^{3}\right]$

dengan $f^{\prime} c=$ kuat tekan beton uji silinder 28 hari $(\mathrm{MPa}), w_{\mathrm{c}}=$ berat satuan beton $\left(\mathrm{kgf} / \mathrm{m}^{3}\right)$.

\section{Dokumentasi Pengujian}

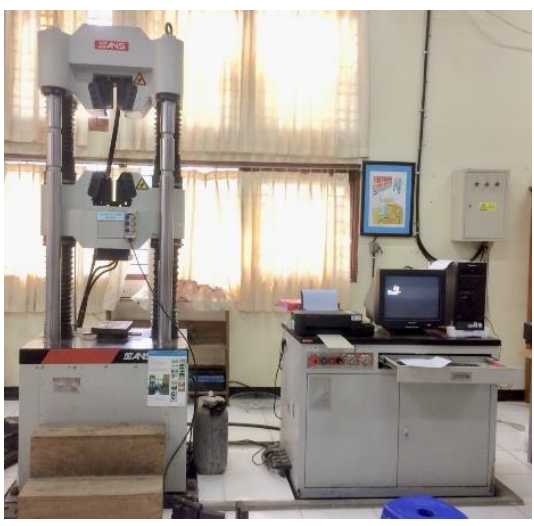

Gambar 1. Universal Testing Machine

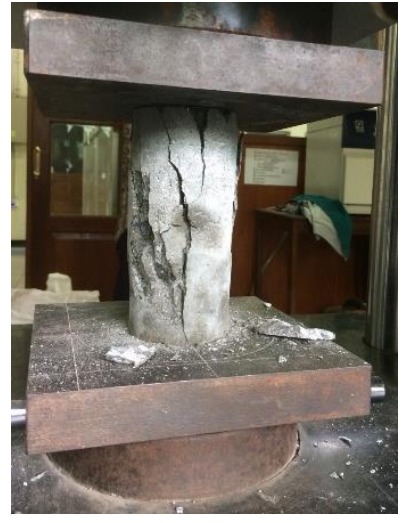

Gambar 2. Pengujian sampel

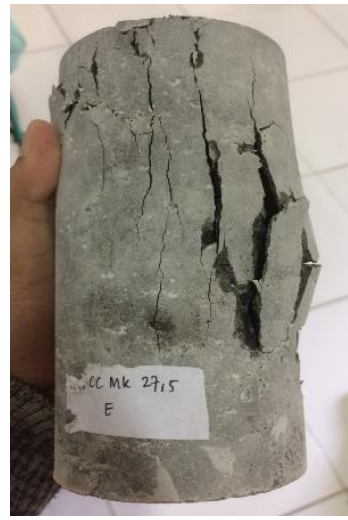

Gambar 3. Sampel yang hancur

\section{HASIL DAN PEMBAHASAN}

\section{Metakaolin}

Penambahan metakaolin (MK) membantu menutupi rongga-rongga yang terbentuk akibat hidrasi semen dan dapat meningkatkan kepadatan yang mengakibatkan kuat tekan naik, dimana metakaolin yang merupakan pozzolan bereaksi dengan senyawa $\mathrm{Ca}(\mathrm{OH})_{2}$ hasil sampingan pada saat hidrasi semen yang menghasilkan C-S-H untuk perekat tambahan dalam campuran beton. Kandungan kimia yang terdapat pada metakaolin dapat diketahui dengan alat $X$-Ray Fluorosence $(X R F)$ yang diuraikan dalam Tabel 3. 
Tabel 3. Kandungan kimia metakaolin hasil uji XRF

\begin{tabular}{lcrlrr}
\hline Formula & $\mathrm{Z}$ & Concentration & Status & Line 1 \\
\hline $\mathrm{SiO} 2$ & 14 & 61,97 & $\%$ & Fit spectrum & Si KA1/EQ20 \\
\hline $\mathrm{Al} 2 \mathrm{O} 3$ & 13 & 16,34 & $\%$ & Fit spectrum & Al KA1/EQ20 \\
\hline $\mathrm{Na} 2 \mathrm{O}$ & 11 & 7,92 & $\%$ & Fit spectrum & Na KA1/EQ20 \\
\hline $\mathrm{CaO}$ & 20 & 4,31 & $\%$ & Fit spectrum & Ca KA1/EQ20 \\
\hline $\mathrm{Fe} 2 \mathrm{O} 3$ & 26 & 2,01 & $\%$ & Fit spectrum & Fe KA1/EQ20 \\
\hline $\mathrm{P} 2 \mathrm{O} 5$ & 15 & 1,58 & $\%$ & Fit spectrum & P KA1/EQ20 \\
\hline $\mathrm{K} 2 \mathrm{O}$ & 19 & 1,58 & $\%$ & Fit spectrum & K KA1/EQ20 \\
\hline $\mathrm{MgO}$ & 12 & 1,22 & $\%$ & Fit spectrum & Mg KA1/EQ20 \\
\hline $\mathrm{SO} 3$ & 16 & 1,14 & $\%$ & Fit spectrum & S KA1/EQ20 \\
\hline $\mathrm{Cl}$ & 17 & 1,00 & $\%$ & Fit spectrum & Cl KA1/EQ20 \\
\hline $\mathrm{TiO} 2$ & 22 & 0,36 & $\%$ & Fit spectrum & Ti KA1/EQ20 \\
\hline $\mathrm{La} 2 \mathrm{O} 3$ & 57 & 0,13 & $\%$ & Fit spectrum & La KA1/EQ50 \\
\hline $\mathrm{MnO}$ & 25 & 0,08 & $\%$ & Fit spectrum & Mn KA1/EQ20 \\
\hline $\mathrm{SrO}$ & 38 & 0,06 & $\%$ & Fit spectrum & Sr KA1/EQ20 \\
\hline
\end{tabular}

Pengujian Beton Segar (Workability) HSSCC Metakaolin

Tabel 4. Hasil pengujian workability beton segar

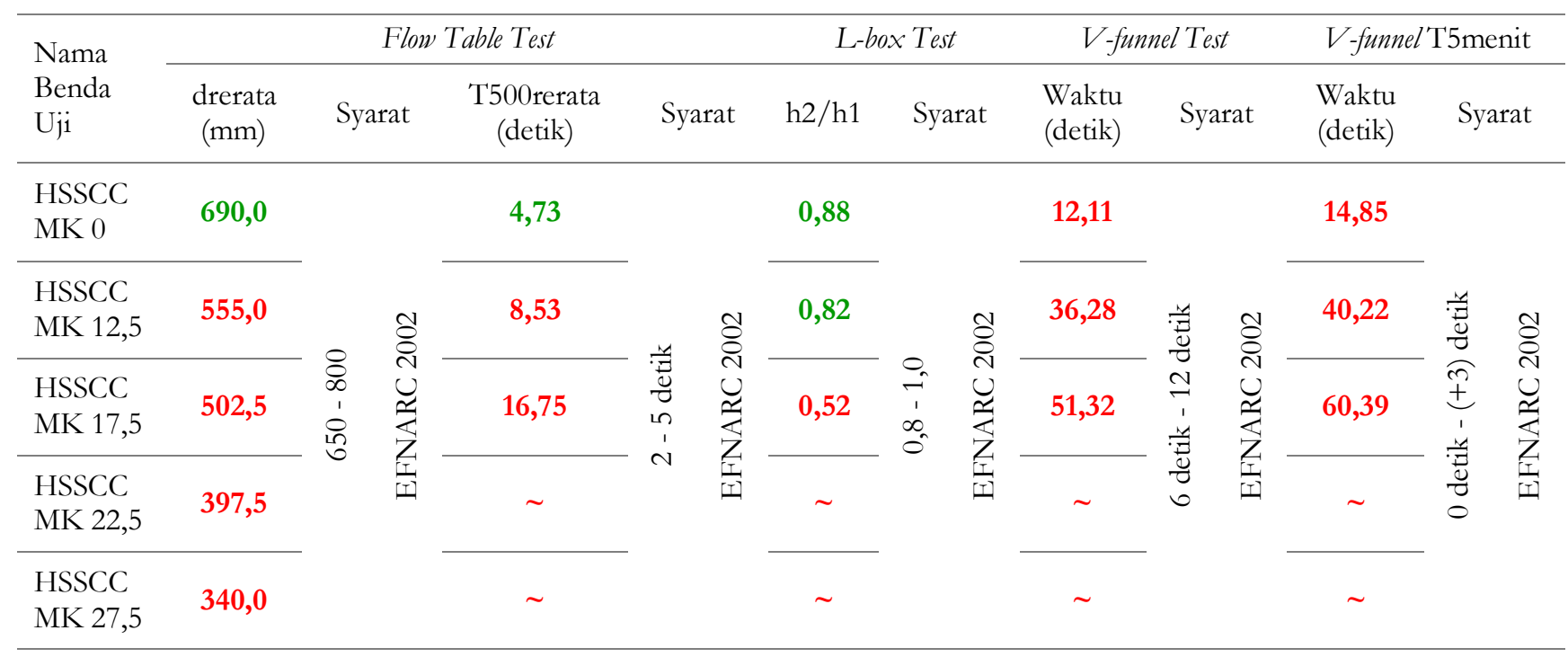

Tabel 4 menunjukkan bahwa semakin bertambahnya kadar metakaolin pada campuran beton mengakibatkan penurunan workability dapat dilihat dengan diameter sebaran beton yang semakin kecil menandakan viskositas campuran beton kental dan seiring bertambahnya kadar metakaolin waktu yang dibutuhkan untuk fillingability, passingability, dan segregation resistance campuran beton semakin lama dikarenakan butiran partikel metakaolin yang sangat kecil dapat menyerap lebih banyak air sehingga campuran beton dengan kadar metakaolin tinggi akan lebih menyerap banyak air dan lebih kental.

\section{Analisis Modulus Elastisitas Beton HSSCC Metakaolin}

Hasil modulus elastisitas yang tinggi memiliki arti kekuatan pada beton tersebut tinggi dengan dipengaruhi juga oleh bahan penyusun beton terutama pemilihan terhadap penggunaan agregat kasarnya. Penghitungan modulus elastisitas pada penelitian ini membandingkan antara modulus elastisitas hasil eksperimen dengan modulus elastisitas hasil prediksi. Dimana nilai modulus elastisitas beton berkisar antara 20.000 MPa sampai dengan 50.000 MPa. 
Tabel 5. Rekapitulasi penghitungan modulus elastisitas hasil eksperimen dan hasil prediksi

\begin{tabular}{|c|c|c|c|c|c|c|}
\hline \multirow[b]{2}{*}{ No. } & \multirow{2}{*}{$\begin{array}{c}\text { Parameter } \\
\text { (Modulus } \\
\text { Elastisitas) }\end{array}$} & \multicolumn{5}{|c|}{ Jenis Benda Uji } \\
\hline & & $\begin{array}{l}\text { HSSCC } \\
\text { MK } 0\end{array}$ & $\begin{array}{l}\text { HSSCC } \\
\text { MK } 12,5\end{array}$ & $\begin{array}{l}\text { HSSCC } \\
\text { MK } 17,5\end{array}$ & $\begin{array}{l}\text { HSSCC } \\
\text { MK 22,5 }\end{array}$ & $\begin{array}{l}\text { HSSCC } \\
\text { MK } 27,5\end{array}$ \\
\hline 1. & ASTM C469 & 28498,51 & 38116,20 & 35509,87 & 30819,70 & 23595,53 \\
\hline 2. & Eurocode 2-1992 & 27878,54 & 37811,60 & 35304,77 & 31171,64 & 23563,73 \\
\hline 3. & $\begin{array}{l}\text { ACI Committee } \\
363-10\end{array}$ & 29186,06 & 32988,37 & 33720,95 & 31193,93 & 29581,95 \\
\hline 4. & Eurocode 2-1992 & 35228,69 & 38555,61 & 39186,56 & 36996,22 & 35579,02 \\
\hline 5. & Kollmorgen & 39679,56 & 43867,45 & 44648,11 & 41920,80 & 40127,09 \\
\hline 6. & $\begin{array}{l}\text { Norwegian } \\
\text { Standard NS } 3473\end{array}$ & 29775,61 & 32727,20 & 33275,55 & 31357,35 & 30091,86 \\
\hline 7. & Norwegian Code & 32436,81 & 35254,80 & 36531,85 & 33412,54 & 32471,03 \\
\hline 8. & SNI $2847-2013$ & 36970,71 & 42796,03 & 44840,23 & 39419,86 & 37271,32 \\
\hline
\end{tabular}

Hasil penghitungan modulus elastisitas beton silinder ukuran diameter $75 \mathrm{~mm}$ dan tinggi $150 \mathrm{~mm}$ umur 28 hari pada Tabel 5 apabila disajikan dalam bentuk grafik dapat dilihat pada Gambar 4.

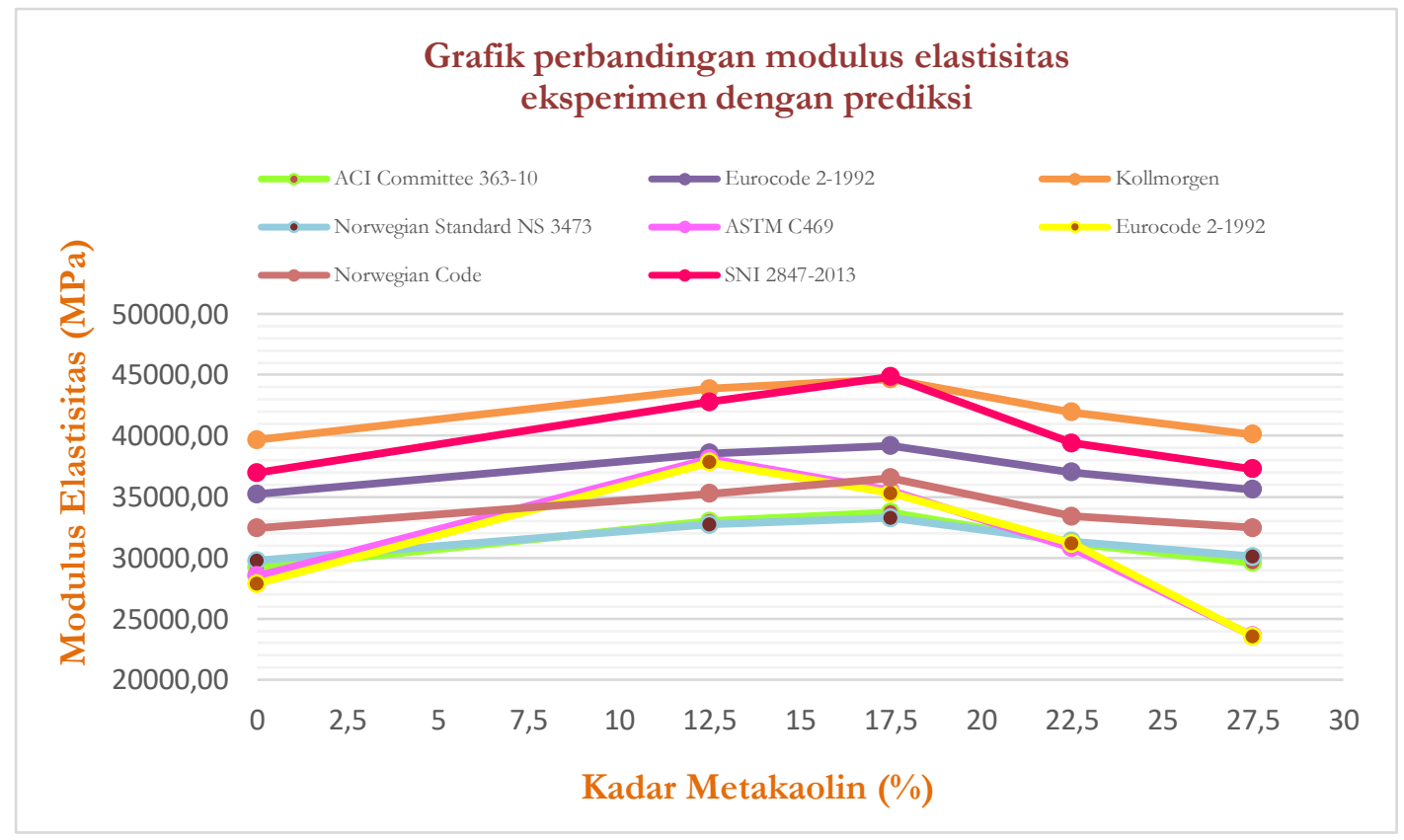

Gambar 4. Grafik perbandingan modulus elastisitas hasil eksperimen dengan hasil prediksi

Gambar 4 menunjukkan bahwa modulus elastisitas mengalami kenaikan dan penurunan. Akan tetapi, kenaikan tertinggi terdapat di kadar yang berbeda antara hasil eksperimen dengan hasil prediksi. Modulus elastisitas hasil eksperimen tertinggi pada kadar 12,5\% metakaolin, dikarenakan tinjauan penghitungan menggunakan hasil kuat tekan sebesar $0,4 f^{\prime} c$ dan regangan hasil interpolasi ketika $0,4 f^{\prime} c$ dimana hasil regangan interpolasi kadar $12,5 \%$ lebih kecil yaitu sebesar 0,000653 daripada regangan interpolasi pada kadar 17,5\% yaitu sebesar 0,000739. Kemudian, diperoleh kadar optimum hasil penghitungan berdasarkan ASTM C469 dan Eurocode 2-1992 yaitu 12,18\% dan 12,42\% dengan modulus elastisitas yang dihasilkan sebesar 37594,73 MPa dan 37368,04 MPa. Sementara, penghitungan modulus elastisitas prediksi berdasarkan hasil kuat tekan dan berat volume beton pada saat pengujian. Maka dari itu hasil modulus elastisitas prediksi tertinggi pada kadar 17,5\% metakaolin dari berat semen sebanding dengan hasil kuat tekan. 


\section{SIMPULAN}

Data hasil pengujian, analisis data, dan pembahasan terhadap hasil dari ekperimen penelitian beton mutu tinggi memadat mandiri dengan variasi penambahan bahan metakaolin, dapat ditarik simpulan sebagai berikut:

Modulus elastsitas yang dihasilkan mengalami kenaikan dan penurunan akibat variasi penambahan metakaolin, penghitungan modulus elastisitas eksperimen maksimum dihasilkan pada kadar 12,5\% metakaolin. Sementara, diperoleh kadar optimum hasil penghitungan berdasarkan ASTM C469 dan Eurocode 2-1992 yaitu 12,18\% dan $12,42 \%$ dengan modulus elastisitas yang dihasilkan sebesar 37594,73 MPa dan 37368,04 MPa. Penurunan modulus elastisitas terjadi seiring dengan penurunan tegangan maksimum yang dihasilkan sementara regangan pada saat 0,4fc' yang dihasilkan relatif sama yaitu berkisar antara 0,0006-0,0007. Modulus elastisitas hasil prediksi tertinggi pada kadar 17,5\% metakaolin dari berat semen dikarenakan penggunaan parameter untuk penghitungan modulus elastisitas prediksi berdasarkan hasil kuat tekan beton dan berat volume beton yang dihasilkan.

\section{REKOMENDASI}

1. Perlu penelitian lebih lanjut pada penggunaan kadar metakaolin dengan selisih antar kadar diperkecil. Kadar yang disarankan oleh penulis antara 17\% sampai $25 \%$ metakaolin dari berat semen.

2. Referensi penggunaan jenis superplasticizer yang lain untuk dapat mempertahankan parameter self compacting concrete.

3. Perlu meningkatkan nilai faktor air semen agar mendapatkan workability campuran beton yang bagus dengan tetap memperhatikan syarat beton self-compacting concrete (SCC).

4. Penelitian lebih lanjut pada umur beton yang lebih lama dari 28 hari, seperti 56 hari dan 90 hari untuk melihat hasil reaksi pozzolanik bekerja dengan optimal pada umur beton yang tinggi.

5. Diusahakan untuk checking bekisting terhadap kemungkinan terjadi kemiringan pada hasil beton yang akan diuji, karena beton yang miring berpengaruh terhadap hasil pembacaan alat uji.

\section{UCAPAN TERIMAKASIH}

Ucapan terima kasih pertama ditujukan kepada Allah SWT atas limpahan rahmat dan nikmatnya. Selanjutnya kepada Bapak Wibowo, S.T., D.E.A. dan Bapak Ir. Antonius Mediyanto, M.T. selaku dosen pembimbing yang telah memberi arahan dan masukan dalam penelitian ini.

\section{REFERENSI}

Alsalman, Ali., dkk. 2017. "Evaluation of modulus of elasticity of ultra-high performance concrete". Construction and Building Materials 153, University of Arkansas, Department of Civil Engineering, USA.

Anonim. 1990. "Standar Nasional Indonesia (SNI) 03 - 1974 - 1990 Metode Pengujian Kuat Tekan Beton”. Jakarta: Badan Standarisasi Nasional.

Anonim. 2000. "Standar Nasional Indonesia (SNI) 03 - 6468 - 2000 Tata Cara Perencanaan Campuran Tinggi dengan Semen Portland dengan Abu Terbang". Jakarta: Badan Standarisasi Nasional.

Anonim. 1993. ASTM C 618-94a. "Standard Specification for Coal Fly Ash and Raw or Calcined Natural Pozzolan for Use in Concrete".

Anonim. 2002. EFNARC. "Specification and Guidelines For Self-Compacting Concrete".

Anonim. 2005. EFNARC. "The European Guidelines for Self-Compacting Concrete Spesification, Product and Use".

Bilir, Turhan. 2016. "Investigation of performances of some empirical and composite models for predicting the modulus of elasticity of high strength concretes incorporating ground pumice and silica fume". Construction and Building Materials 127, Bulent Ecevit University, Faculty of Engineering, Department of Civil Engineering, Farabi Campus, Turkey.

Emir A Dharmawan. 2017. “Kajian Pengaruh Variasi Komposisi Metakaolin terhadap Parameter Beton Memadat Mandiri dan Kuat Tekan Beton Mutu Tinggi”. Program Studi Teknik Sipil Fakultas Teknik Universitas Sebelas Maret, Surakarta.

Galang Nur A Pamungkas. 2017. "Pengarub Rasio Diameter / Tinggi Spesimen terbadap Hubungan Tegangan dan Regangan pada Beton High Volume Fly Ash Self Compacting Concrete”. Program Studi Teknik Sipil Fakultas Teknik Universitas Sebelas Maret, Surakarta.

Istimawan Dipohusodo. 1994. "Struktur Beton Bertulang”. Jakarta: Gramedia Pustaka Utama.

Patil, S.N., Gupta, A.K., dan Deshpande, S.S. 2012. "Metakaolin-Pozzolanic Material for Cement in High Strength Concrete”. Dept. of Civil Engg., Dr. JJMCOE, Jaysingpur, M.S. India.

Sholihin As’ad. 2012. “Beton Memadat Mandiri”. Harian JOGLOSEMAR. 12 Agustus 2012. 